\title{
Metacognitive Strategies in Learning Sight-Singing
}

\section{Blanka Bogunović ${ }^{2}$ \\ Faculty of Music, University of Arts, Belgrade, Serbia}

\author{
Ida Vujović \\ Royal Conservatoire, The Hague, The Netherlands
}

This paper presents a part of a wider study that is based on interdisciplinary research of sight-singing (psychology and music education). Our intention was to join the psychological knowledge of cognitive processes on the one hand, and the practical approach of music teachers, based on methods, techniques and procedures of mastering sight-reading-singing skills on the other. We aimed: 1. to determine the kinds and levels of strategies that music students use in the cognitive processes involved during sight-singing; 2. to explore strategies of problem solving when difficulties appear; 3 . to investigate the self-evaluation perspectives of students; and 4. to relate students' learning experience to the strategies used. The sample consisted of 89 music students from higher music education in Belgrade and The Hague. They filled in the questionnaire based on self-reports, covering general data about their music education background, different issues of sight-singing, such as planning, problem solving, monitoring and evaluation of outcomes, and three melodic examples written in different musical styles. Results showed that strategies used during sight-singing can be roughly sorted into three groups that differ according to the "key accent" given: cognitive, intuitive and no-strategy. The music cognitive strategies involved cover three levels of musical organization and representation: a) relying on smaller chunks of the musical piece, referring to existing knowledge and learning experience; b) leaning on a slightly "bigger picture" of familiar patterns;

1 This is the extended version of the paper presented at the 12th ICMPC and 8th ESCOM joint Conference, on 23-28 July 2012 in Thessaloniki, organized by the Department of Music Studies, School of Fine Arts, Aristotle University of Thessaloniki, and the European Society for the Cognitive Sciences of Music. The research for this article was carried out as a part of the project Identification, measurement and development of the cognitive and emotional competencies important for a Europe-oriented society (No. 179018) supported by the Ministry of Education and Science, Republic of Serbia (2011-2014) and within the framework of the project Widening Participation on the Road to Membership (2009-2011), supported by SIDA and AEC. 
and c) mental representation of melodic/rhythmic/harmonic structures. When faced with a problem, half of the students employed analytic approaches. Comparisons between sub-samples showed, for example, that future performing musicians more often used "tone-to-tone" thinking and "bottom-up" strategies in approaching musical structure, while music theory students had better insight into the whole and used "top-down" strategies. Research results provide a possibility for evaluation of learning outcomes and improving teaching practices.

Key words: sight-singing skills, metacognitive strategies, self-regulated learning

\section{Introduction}

This article presents part of the results of a wider interdisciplinary empirical research investigating cognitive strategies in sight-singing, an issue that is interesting and important for both disciplines engaged: psychology of music and music education/theory. We had the intention of joining the psychological knowledge of cognitive processes on the one hand, and the practical approach of music teachers, based on methods, techniques and procedures of mastering sight-reading-singing skills on the other. According to Sloboda (1985), the sight-reading skill, as one of the basic skills of successful vocal-instrumental performers, being based on extremely complex cognitive and musical mechanisms, is a very important indicator of the level of musical abilities and musical competencies, more valid and reliable than the final, expert performance that is presented at music examinations and competitions (Sloboda, 1985). Shifting the focus of investigation to the process which precedes the final result of performance could result in gaining more knowledge (theoretical, methodological and practical) of musical-mental actions and, therefore, contribute to its better understanding and explanation of the sight-reading-singing/playing skills. The only way to reach this goal is to join psychological knowledge and experience of musical practice teaching/learning and professional performing (Radoš, 2010). The sightsinging has not been investigated much in the field of cognitive psychology of music; much more attention was paid to the instrumental sight-reading of solo or orchestra players.

Musicians usually tend to have an overview of the piece they intend to play or sing and the way to acquire this is to have a good internal aural representation of the music from examination of the score only (Hallam, 2006), which also could be referred to as inner hearing. Sight-readingsinging is a specific musical skill which encompasses the ability to imagine the sound of the score while looking at it for the first time (also noted as $a$ prima vista (ital.), and the ability to reproduce this sound by voice. It signifies performing from the score at the level of rehearsed performance, but without or with just brief preparation. At first sight, there is much similarity between this and the process of sight-reading-playing an instrument. Hence, the first 
phase of the process is reading the notes from the score (visual perception of the score) and the second is realization of the sound, by singing or playing an instrument. However, as much as they may have in common, these two activities engage different skills. Playing from sight involves music motor skills, while singing from sight involves the ability to imagine the sound and perform it. Although, naturally, sight-singing is a skill needed by professional singers, the ability to 'hear' the notes before one is going to play them (even when the notes will not be sung) is highly desired by all instrumentalists as well. This skill is especially important in western classical tradition because of the dominance of notation. Sight-reading and sight-singing skills are compulsory, especially at the level of higher musical education, as well as at the auditions for orchestras and chamber music ensembles.

Sight-singing is an "online" activity that asks for quick insight and problem solving in order to maintain fluency and accuracy without interrupting the musical stream. Performing (singing or playing) is produced in response to a succession of visual stimuli presented in real time. The speed of stimuli presentation is in function of the chosen tempo and the relative density of musical events. The sequence of steps is: perceiving notation, processing it and executing the resulting motor (or vocal) program (Thompson \& Lehmann, 2006). The ability to perform on sight, with little or no preparation, may be regarded as a reconstructive activity that involves higher-level mental processes, which are initiated primarily by visual input but also by conceptual knowledge and specific expectations (Lehmann \& McArthur, 2002). In the process of sight-reading, memory plays a significant role considering reconstructing knowledge and previous experience. Namely, long-term memory is important in holding information on procedural knowledge ("knowing how" to do something), semantic knowledge (facts, e.g. "knowing that") and episodic memory (details of events or episodes of one's life). Procedural knowledge underlies performer's ability to make music (the widest sense of the word) in terms of playing the instrument or singing. However, the knowledge that a particular sequence of notes represents certain patterns (e.g. D major scale, or rhythm and meter, melody, etc.) depends on semantic memory. Meanwhile, specific associations of an individual referring to a certain melody are stored in episodic memory (Ginsborg, 2004). During sight-reading, pattern recognition is in progress and it is related to long-term working memory, which supposes that experts are able to access quickly the contents of their long-term memory. In order to manage that, musicians need to possess a mental template that serves as the focus for all learning and performance activities (Whitaker, 1996). Combinations of notes that occur frequently over time are stored in memory as discrete entities/ patterns and they can be easily retrieved from memory and used in novel contexts. Experienced sight-readers take larger chunks of visual information and generate more accurate predictions about what may be coming next. 
This process encompasses mechanisms of interference, anticipation and guessing (Thompson \& Lehmann, 2004). It is backed up by the previous knowledge and expectations, when recognition of shape (gestalt) and pattern is activated (Lehmann \& Chaffin, 2008). When music contains predictable or straightforward patterns, musicians are more likely to look ahead and anticipate the flow of the musical piece (Sloboda, 1988).

Sight-reading provides a complex problem solving situation with an intricate interplay of "bottom-up" mechanisms (driven by the input stimulus of the score and auditory feedback) and "top-down" processes (driven by expectations and cognitions) (Lehmann \& Kopiez, 2008). The application of different problem solving strategies is influenced by relevant background knowledge, which helps to classify problems, perceive their underlying structure and, therefore, understand critical components of the problem. Domain knowledge allows better perception of the most important part of the problem which should be addressed and, thereby, restricts the search to the key part of the problem. Another way in which the domain knowledge can help problem solving is by automatizing some of the problem-solving steps so they do not demand attention (Willingham, 2007).

High level of sight-singing skills pertains to expert thinking that is characterized by prompt execution of tasks, by perceiving meaningful units and using their operative and long term memory more efficiently. Experts grasp the problem on a deeper level by noticing the relevant aspects of the phenomena; they observe the problem from different angles before they opt for a solution. They have the ability to monitor their activities and, therefore, correct themselves during the process of executing certain operations (Kostić, 2010). It is confirmed that those sight-singers with higher level of selfassessment skills, have better insight into the structure of a melodic task and rely on inner hearing (Vujović \& Bogunović, 2012a).

In the educational context, developing the skill to generate audio schemata from written notation is usually associated with sight-singing, which is taught in the framework of solfège tuition. This skill is usually referred to as inner hearing, which relies on "musical thinking" - a process which comprises mental/auditory representations of not only individual tones but of tonal relations, harmony, polyphony and timbre, as well. Students should be able to analytically follow details of musical flow, to construct the mental representation of the whole piece, to perceive bigger structures and to get the idea of the sound architecture (Kršić Sekulić, 2009). The essence of the process which starts with visual perception of the score and recognition of the organized units of musical phrases (gestalt) has vocal reproduction as the output and is based on grasping micro and macro structures of melodicrhythmical flow (Kiselčić Todorović, 1995). The two pedagogical directions are always present in solfège instruction: one, which puts emphasis on 
enriching the music vocabulary by practicing melodic/rhythmic/harmonic elements, and the other, where the focus is on understanding of musical flow and content, expressivity, musicality (Vujović \& Bogunović, 2012b).

Mastering inner hearing skills, which are an essential part of the sightsinging process, is an important educational goal because these skills are inherent prerogatives for active engagement/involvement in music. There are many methods to achieve this goal and most of them rely on creating associations of some sort that will help in finding the right pitch when seeing a note. As these associations are of different kinds and levels (tonal-functional, intervallic, mnemonic, etc.), students learn to develop strategies for choosing and using them while singing. If they start at an early age, pupils develop this skill through a "trial and error" learning approach; at a later age this process is basically cognitive, in the sense of a problem solving. The final goal of sightsinging instruction is a routinized skill which enables the student to "hear" notated music through the combination of melodic, rhythmic, harmonic and structural reading. According to the research results, when pupils who had mastered the skill until the age of 15 were involved, factors which influence mastering of sight-reading skills were practice-related (sight-reading expertise and inner hearing) and practice-unrelated skills (elementary skills genetically determined: motor accomplishment and quick mental processing) (Kopiez \& Lee, 2006; 2008). The accumulated effect of a longer period of acquiring education, but also of getting more mature, was shown in the study in which the correlations between the two aspects of performance, namely, sightreading skills and the ability to perform a repertoire of rehearsed music, seem to strengthen markedly (McPherson, 1994).

While many books are written to help teaching sight-singing, developing learning habits and strategies is often left to students themselves. At a time when Lifelong Learning is becoming an unavoidable concept, the transferable and reflexive skills needed for autonomous learning or practicing are becoming essential. One of the implications of this concept is the focus on learning instead of on teaching (Smilde, 2009; Vujović, 2012). More precisely, the educational objective is to enable students to set goals, learn and evaluate the outcomes independently. These ideas bring us to the concept of selfregulated learning, which comprises deliberate thinking, performing tasks and self-reflection, which refers to the awareness of the output quality and performing experience and represents a basis for evaluation. The importance of having a repertoire of strategies, ready for use in every phase of performing (sight-singing in this case) is a crucial part of "metacognitive knowledge" (Jorgensen, 2004).

Borkowski and Turner (1990) have suggested three areas of metacognitive knowledge which can be applied in learning musical skills: specific knowledge of strategies already known, relational knowledge that covers the knowledge of how different strategies may contribute to reaching various tasks and goals 
and general knowledge which has to do with the understanding of how much effort is required when employing practice strategies. Several studies have shown that practitioners have a restricted knowledge of specific strategies and that there are considerable differences between beginners, novices and experts (Hallam, 2001; Sloboda et al., 1996), as well as individual differences among musicians at the same level of accomplishment (Nielsen, 1999, 2001).

Metacognitive strategies are crucial to all aspects of music practice and they cover planning, monitoring and evaluation, which lead to selfregulated learning when they are well developed. Well developed metacognitive skills include self-awareness of strengths and weaknesses, extensive knowledge regarding the nature of different tasks, strategies in order to respond to different needs (Hallam, 2006). The acquisition, enhancement and development of strategy repertoire and knowledge about them, as well as awareness of individual abilities and potentials, are certainly one of the most important goals for anyone who is engaged in music performance activities.

Starting from the two folded approach to sight-singing, the underlying psychological processes, on the one hand and the strategies students use to master a sight-singing task on the other, we wondered how students learn sight-singing: to what extent do they try to understand/follow the whole of a music example/piece, and to what extent are they aware of the musical parameters? How do they define the difficulties they meet? How do they solve these problems? To what extent are they aware of the domain-specific cognitive strategies which they use in the course of sight-singing an unfamiliar melodic exercise? We were interested in the ways in which music students apply their knowledge of specific and relational strategies, such as using theoretical musical knowledge, skills and experience, then planning, problem solving, monitoring and evaluating outcomes, which can lead to effective self-regulative learning. The research has a cross-cultural perspective through comparisons of students from different music educational systems and hence with specific musical backgrounds. It is meant to be a pilot research, diagnostic, with the intention of discovering students' habits and strategies that need more attention or are interesting for further exploration.

\section{Method}

We aimed to:

- Determine the kinds and level of strategies music students use in the cognitive processes involved during the first contact with unfamiliar melodic examples, namely sight-singing;

- Explore strategies of problem solving when difficulties appear;

- Investigate the self-evaluation perspectives of students;

- Relate students' learning experience to the strategies used. 
Explorative empirical research was used. The sample consisted of 89 music students from the Faculty of Music in Belgrade $(\mathrm{N}=65)$ and the Royal Conservatoire in The Hague $(\mathrm{N}=24)$. Students were aged from 17 to 30,41 male and 48 female. They played many different instruments, but for the purpose of the study we grouped them into a performers group (piano 20 ; strings 24 ; wind and singers 19$)(\mathrm{N}=55)$ and a music theory group (including students of pedagogy, conducting and composition) $(\mathrm{N}=34)$; as well as into jazz $(\mathrm{N}=12)$ and classical music direction $(\mathrm{N}=77)$. They had played instruments (major and minor subject) for between 1 and 17 years and learned solfège (as major for music theory/pedagogy departments or minor for instrumentalists) for between 1 and 15 years. The sample was rather heterogeneous. Some of the sample from The Hague Conservatory had had only one year of systematic solfège instruction prior to our inquiry (because there is no systematic long-term education before higher music education); others had longer experience, due to the fact that they had had previous education in other countries. Students from the Belgrade Faculty of Music had already received 8 to 10 years of specialized music education, where solfège was continuously taught.

Participants filled in the questionnaire (28 self-report items) which had three parts: first, general music education background, then multiple choice with the possibility of choosing appropriate answers or "open-ended" items considering different issues of sight-singing: experience and didactical methods used in learning solfège, habits during individual solfège practice, use of a musical instrument, ways of problem solving, reflection upon the learning process and evaluation of outcomes. The third part consisted of three melodic examples written in different musical styles (classical, jazz, and quasi-atonal). The students were asked to sing them and reflect upon their own performance, considering different aspects of sight-singing.

Variables included in the research study addressed: general data (music direction, instrument played, country of study), learning experience (duration of instrumental and solfège instruction, didactic methods used), awareness of own skill and knowledge of musical elements (awareness of "strong" and "weak" points), cognitive strategies used (in preparation, practicing, melody segmentation, defining and solving difficulties), and selfevaluation of educational outcomes. The questionnaire was handed out by the solfège teachers and students had to fill it in during the lesson or at home. The questionnaire was semi-anonymous, and only the students' numbers (optional) were requested in case they were to participate in the next stages of the research. Qualitative content analysis and quantitative data analysis (SPSS 17.0) were applied. In both cases, data were represented as categorical variables, binary or using a five-point Likert-type scale. Statistical analysis was applied: descriptive, $\chi$ square and correlation. 


\section{Results}

The results are presented according to the previously stated aims of the research. Each section refers first to the students' answers about the processes during sight-singing in general, and subsequently to the analysis of students' answers related to one of the three melodic examples given in the questionnaire, the one in jazz style, as illustration (see Figure 1, disregard the lines above the notes).

\section{A. Strategies Involved in Sight-singing}

The results considering methods that the students reported using prior to and during performing the melodic examples (in general) strongly suggest that there are several (music) cognitive strategies, differing in their level of complexity, which were applied. They provided kinds of deliberate action objectives for the sight-singing process. Other reported strategies include "relying on musical intuition" and "immediate singing" (Table 1). At the first contact with an unfamiliar melodic example, so before singing it, approximately half of the students tend to analyze the melody in order to make a preview of the elements they think are important for performing it in the best possible way. Their approach seems to be also with a view to getting an insight into the metric and harmonic organization of the example in order to have general orientation. We could say that, at this point, they refer to the previously learned patterns and the recognition of the already known melody chunks.

It seems that strategies that are used during sight-singing can be roughly sorted into three groups that differ in the "key accent" given: cognitive, intuitive or no-strategy ("immediate start of singing"). The cognitive strategies involved cover three levels of musical structure organization and representation: a) the most frequent was relying on smaller chunks of the musical piece, mostly referring to the application of existing knowledge and learning experience (e.g. tonal functions of certain tones, recognition of known intervals, important tones, sequences of tones); b) relying on a slightly "bigger picture" as an orientation for performing through recognition of familiar patterns (e.g. tonal, harmonic and rhythmical); and c) mental representation, e.g. inner hearing, of melodic/rhythmic/ harmonic structure. We could say that the proportion is opposite - the higher the hierarchical level of the strategies used (from tone to harmonic organization and mental representation), the smaller the percentage of its representation. 
Table 1: Sight-singing habits and strategies in general (during preparation and performing).

\begin{tabular}{|c|c|c|}
\hline Students' strategies & Frequency & $\%$ \\
\hline \multicolumn{3}{|l|}{ Before sight-singing } \\
\hline Making an analysis before singing & 45 & 51 \\
\hline Determining the meter and the key before singing & 48 & 55 \\
\hline \multicolumn{3}{|l|}{ During sight-singing } \\
\hline I focus on stable tones & 39 & 44 \\
\hline I recognize known intervals, motives, tonal relations & 41 & 46 \\
\hline I focus on important tones in the melody & 21 & 24 \\
\hline $\begin{array}{l}\text { In the case of a difficult leap, I sing other notes (e.g. the scale) } \\
\text { to help me find the right pitch }\end{array}$ & 21 & 24 \\
\hline I think of the harmonic progression & 25 & 28 \\
\hline I pay attention to rhythm groupings & 10 & 11 \\
\hline I think of the tonal plan of the melody & 4 & 5 \\
\hline I often sing tonic in my "inner hearing" & 20 & 23 \\
\hline I "hear" the tones ("inner hearing") before I sing them & 29 & 33 \\
\hline I rely on my musical intuition & 31 & 35 \\
\hline Immediate start of singing & 16 & 18 \\
\hline
\end{tabular}

Rather interesting is the "relying on intuition" strategy, which is a bit vague to explain since it is not quite clear if this kind of "using automatic pilot" implies "not thinking at all" or relies on tacit knowledge. There is a view that it could be understood as using knowledge that is automatically retrieved from long-term memory and that there is no active awareness of it (BeočaninMijanović, 2008; Lehmann et al., 2007), which would indicate highly learned and integrated skills of sight-singing. Starting sight-singing "immediately" could be understood as a no-strategy approach (this is often met by students with developed absolute pitch) or a no-deliberate approach, which would mean that either students are not aware of the automatic strategies they use or they have a "trial and error" strategy or are not concerned about the sightsinging results. What is interesting anyhow is that none of the strategies used is really prevalent, and none of them is represented by more than $46 \%$. This means that students use a considerable number of diverse strategies and also several simultaneously, which implies the presence of divergent approaches towards sight-singing.

The utilization of musical instruments as an "auxiliary strategy" is certainly expected, and could also be useful during the learning process. In the long run, however, the concrete procedures could be expected to change. Students use their instruments mostly to check intonation during singing (56\%) or to check the last tone (24\%). $34 \%$ of the student sample use the instrument to 
hear difficult leaps, which could be regarded as too often, since this strategy is often discouraged in solfège lessons. Using instruments happens more often in the performers group $\left(\chi^{2}=4.54(1) ; \mathrm{p}<0.03\right)$, which is understandable. So, this "auxiliary strategy" or "help strategy" is present in up to $56 \%$ of the student sample at the beginning level of higher music education, which could suggest "field-dependent" (Witkin et al., 1977) musical behavior. There is a tendency (though not statistically significant) for good sight-singers not to use instruments as their auxiliary strategy.

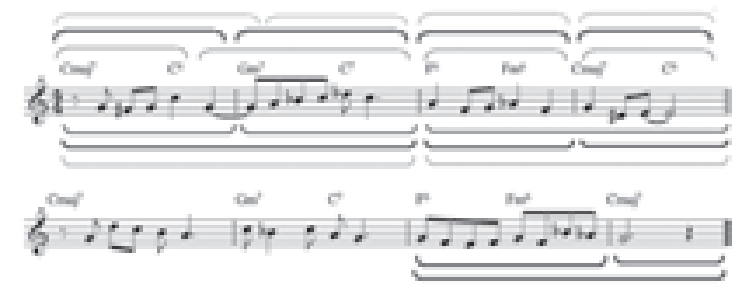

Figure 1. Structural segmentation according to students' analysis. Micro (one bar), medium (two bars) and macro (four bars) level

(Melodic example: The Berklee Correspondence Course (lesson 5).

Boston: Berklee Press Publications. [original exercises no. 19 and 20, changed mm.1,2, 6, added chord extensions]).

The students' answers relating to the melodic example in the third part of the questionnaire showed how their general statements were applied in concrete sight-singing. Related to preparation prior to sight-singing, most students reported taking a general overview of the melody, at least checking the meter and the key(s) (69\%). Many students also reported analyzing basic "solfège parameters", such as difficult leaps, intervals or alterations (31\%). Not so many reported making a preview of the harmonic progression (19\%). This is interesting given that this melodic example comes with chord symbols above the notes (Figure 1). Voice preparation (10\%) is actually a kind of tuning or setting of the auditive frame for the melody. Some students analyzed melodic structure (8\%), while some did not do any analysis or preparation (11\%). It is noticeable that rhythm had a relatively low role in preparation, which could also be a consequence of the rather simple/transparent rhythmical pattern of the melodic example. However, it is known that in the encoding of the unknown melodies, pitch and contour information are better memory cues than the rhythm (Kopiez \& Lee, 2008). But it was also noticeable that jazz students reported a focus on rhythm patterns more often than classical music students.

We asked the participants to mark any group of notes (phrase, motif, figure) they perceived during singing. We assumed that structural segmentation could be one of the cognitive strategies involved and that students who have better insight into the whole structure would have better outcomes. We 
were investigating the type and hierarchical level of segmentation, as well as the completeness and absence of segmentation (Table 2). When the type of segmentation was in question, the highest proportion of answers referred to structural groups (59\%). We listed in this category all the markings where it was clear that metrical proportions played a decisive role (Figure 1). Melodic figures and motives (26\%) could also be one-bar long, but are categorized as such when the segmentation does not cover the whole melody or when other type of note-grouping is also present. Visual perceptive chunks (16\%) refer to groups of notes that form visual units that cannot otherwise be considered a musical unit (e.g. stepwise progression, symmetric leaps, etc.). The inner logic of all three groupings is distinct - formal, music-logical and perceptive. We noticed that students who did not find this melodic example difficult perceived units on the higher level of abstraction, meaning also bigger wholes.

Table 2: Segmentation - type, level and completeness (Melodic example)

\begin{tabular}{|l|c|c|}
\hline \multicolumn{1}{|c|}{ Type of segmentation } & Frequency & $\%$ \\
\hline Structural grouping & 51 & 59 \\
\hline Melodic figures and motives & 22 & 26 \\
\hline Visual perceptive chunks & 14 & 16 \\
\hline Non-logical grouping & 11 & 13 \\
\hline Rhythmic figures and motives & 0 & 0 \\
\hline \multicolumn{1}{|c|}{ Hierarchical level of segmentation } & & \\
\hline Combination/Mix & 27 & 31 \\
\hline Medium level & 21 & 24 \\
\hline Micro level & 14 & 16 \\
\hline Macro level (four bars and more) & 3 & 4 \\
\hline \multicolumn{1}{|c|}{ Completeness and absence of segmentation } & & \\
\hline Complete & 56 & 64 \\
\hline No segmentation & 19 & 22 \\
\hline
\end{tabular}

It is worthwhile considering that a rather large number of students (22\%) did not make an attempt to gain an insight into the structure of the melody through segmentation. The most frequent level of segmentation the students made was a combination of the medium and micro level (structural segmentation including two-bar groups, and melodic and rhythmic figures and motives, one bar, respectively).

\section{B. Problem Solving Strategies}

Perhaps the most important aspect of self-regulated learning is the question of perceiving and defining the problem and then choosing the way to (try to) solve it, eventually identifying the missing skills and missing knowledge. Hence, 
we wanted to investigate what was always "easy" for students and what kind of insight into musical parameters made it easy; also, what was "difficult" for them, and what strategies they used to solve these difficulties. We asked the students to name some melodic/rhythmic/harmonic elements they can perform in any context. Students listed many single musical elements which we categorized into four groups: "scale degrees" was the most populated category $(\mathrm{M}=2.46$; $\mathrm{SD}=1.73)$, followed by "chords" $(\mathrm{M}=1.33 ; \mathrm{SD}=1.10)$, "rhythmical figures" $(\mathrm{M}=1.00 ; \mathrm{SD}=1.12)$ and "intervals" $(\mathrm{M}=0.98 ; \mathrm{SD}=1.49)$. These data reflect the methodical approach used in the majority of solfège methods/schools, namely a focus on tonal functions. In concordance with this is the result that students who have learned solfège for less than 5 years more often report singing the tonic to (re-)establish the key or to check performance $\left(\chi^{2}=11.34(2) ; p<0.0\right)$, which is one of the first strategies learned in various functional approaches. When it comes to difficult musical elements (Table 3), the most problematic for students were: "many leaps" (73\%), and then "alterations" (35\%) and "modulations" (24\%), as well as, complex rhythm and meter (28\%). Alterations and, in some cases, series of leaps affect the stability of mental representation of the key (tonality) schemata. This disturbance is often the reason for having difficulties. By modulation, the student has to aurally establish another key centre, meaning that, at a certain point, tonality is very unstable. In order to sing accurately (except in the case of having absolute pitch), one must be able to tonally orientate and keep the frame of reference.

Table 3: Elements difficult for sight-singing

\begin{tabular}{|l|c|c|}
\hline \multicolumn{1}{|c|}{ Difficult elements } & Frequency & $\%$ \\
\hline Many leaps & 64 & 73 \\
\hline Altered tones & 31 & 35 \\
\hline Complex rhythm and meter & 25 & 28 \\
\hline Modulation in melody & 21 & 24 \\
\hline Tonality with many sharps or flats & 6 & 7 \\
\hline When melody does not start with tonic & 4 & 5 \\
\hline Fast tempo & 1 & 1 \\
\hline Tones out of voice range & 1 & 1 \\
\hline Nothing makes it difficult & 4 & 5 \\
\hline
\end{tabular}

When faced with difficulties and "problematic places", students use diverse strategies to solve the problem:

- Practicing in order to "repair" the critical point (57\%) by using previous knowledge and skills, and transferring them to a new situation;

- Some one-third of students reflected on and analyzed possible causes/ reasons for their mistakes $(32 \%)$;

- An "auxiliary strategy" of relying on a musical instrument (playing the "right" tone on it) (28\%); 
- Dysfunctional strategies, such as "singing from the beginning" (10\%) or "singing until the end without stopping" $(8 \%)$, which is the strategy usually used by novices, as previous research showed (Radoš, 2010; McPherson, 1994).

When the given melodic example was in question students were asked to mark on the paper (with different colors) parts of the example that were "easy" and "difficult" for them. Thereafter, they were asked to define the problematic notes and to explain how they would try to solve the problem. As a result, we obtained slightly richer data about the music elements that facilitate sight-singing: "feeling of key" (67\%) which refers to tonal schemata, "intervals" (49\%) and "memory of previously-sung tones" (40\%), which all come from the same source, namely learned skills and knowledge. Elements to rely on, which involve a certain degree of higher organizational level, were: "following the harmony flow" (35\%), "recognition of melodic patterns" (25\%) and "recognition of rhythmical patterns" (10\%). Interestingly enough, some students mentioned psychological attributes they possess as a strong leaning point, namely, concentration and abilities (3\%).

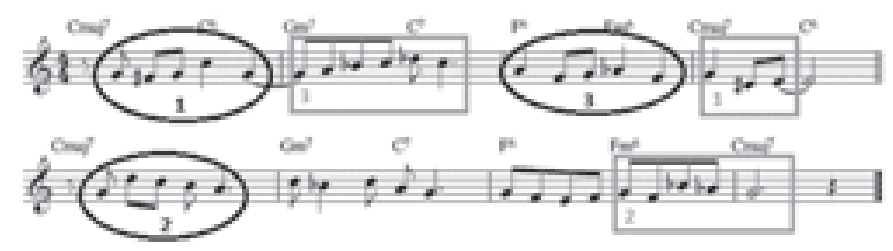

Figure 2: "Easy" and "difficult" bars/notes marked by students (in the melodic example). Oval lines represent "easy" bars/notes and numbers present the grading: 1 is the easiest bar/notes,

3 is the least easy of the three. Rectangular lines indicate "difficult" bars/notes, 1 is the most difficult.

Commenting on their approach to this melody, students repeated the previously expressed statements about the musical elements they found difficult to perform (Figure 2). These were: alterations (38\%), then, leaps, several subsequent leaps, large intervals (29\%) and modulation and "losing the feeling of the key" (17\%). We noticed, when students marked several difficult parts of melodic example, that their segmentation was on a lower level or they did not perceive units. Then tones tended to be grouped by perceptive (visual) closeness.

Reported problem solving strategies, related to the melodic example (openended question) showed in more detail how students work out their abovementioned practice strategies, which they declared using in a general setting (57\% of them). It is clear that they are very much engaged in finding ways 
to overcome difficulties and to master skills, relying significantly on music theory knowledge, solfège skills, simple drill and using well known methods (Table 4). But it is also clear that analysis and looking for solutions were prevalent, mainly based on tonality and harmony, which is very important because grasping harmonies quickly enables performer to sing better and to produce more musically meaningful performances (Karpinski, 2000).

Table 4: Problem solving strategies (Melodic example)

\begin{tabular}{|l|c|c|}
\hline \multicolumn{1}{|c|}{ Problem solving strategies } & Frequency & $\%$ \\
\hline Solutions related to tonality and/or harmony & 20 & 23 \\
\hline Solutions related to intervals and chords & 17 & 20 \\
\hline Drill & 15 & 17 \\
\hline Application of learned methods & 13 & 15 \\
\hline Analysis - looking for a strategy & 2 & 2 \\
\hline Dysfunctional strategies & 8 & 9 \\
\hline
\end{tabular}

One thing is very interesting, considering strategies related to key/harmony: students' definition of difficulties they encountered in this melody revealed that many of them were singing it in $\mathrm{G}$ major (or minor), some of them even modulated to $\mathrm{E}$ minor, while the given chord symbols clearly indicate $\mathrm{C}$ major. This shows they ignored the chord symbols. On the one hand, this could be interpreted as a non-musical approach to sight-singing, since it does not try to reveal the music in the notes, but rather tries to put the notes in the context where they could be easier to sing. As Gary Karpinski already noticed, sightsingers who read by tonal function generally make frequent changes of tonic (switch to 'thinking' in different key), in order to render the melody more easy to execute (Karpinski, 2000). Seeing that students consider alterations (statistically) to be more difficult than modulation, we can conclude that they use modulation as a strategy to solve the problem of alteration.

\section{Self-evaluative Perspectives of Students}

This aspect of self-regulative learning was investigated through selfevaluation of sight-singing skills. We tried to infer the skills of students who estimate themselves to be higher achievers. Also, we were interested in students' awareness of the process of learning, namely monitoring and outcome evaluation.

The results of the self-evaluation of sight-singing skills in general showed that the students' estimation tends to be mainly around average (42\%), then "sometimes good, sometimes bad" (27\%), while the categories "very good" (13\%) and "excellent" (12\%) are not so frequent. A rather small number of students (6\%) perceived themselves as poor achievers. These data bring us to the conclusion that students did not feel confident in their sight-singing skills, which emphasizes the importance of research in this educational area. 
Significant differences exist between the two sub-samples of students (from Belgrade and from The Hague) considering their self-evaluation of their sight-singing skill mastery. Those who had learned solfège, namely sight-singing, for many years (Belgrade) had higher estimations of their skill mastery $\left(\chi^{2}=10.95(4) ; p<0.03\right)$. On the contrary, $54 \%$ of those who had been taught for a shorter period (The Hague) thought that their skill was "poor" or "sometimes good". Supposing that the level requirements are relatively equally far from the students of each group, we could assume that this has to do with the duration of learning solfège: beginners are often aware of all the things that they cannot yet do, while professionals are often (at least also) aware of their knowledge. It is interesting that female students estimated their sight-singing skills as more successful more often than male students $(\mathrm{r}=0.23$; $\mathrm{p}<0.05$ ). There are no significant differences between the sight-singing estimation for different instrumental groups and musical genres.

The findings indicate that those students who had higher opinions of their sight-singing skills had a "bigger picture" of the singing melody, they did not have to recall the tonic often $(\mathrm{r}=-0.31 ; \mathrm{p}<0.00)$, and relied on "inner hearing" or auditive/mental representation of the tones that should be sung $(r=0.45$; $\mathrm{p}<0.00)$. They significantly more often analyzed before singing $(r=0.25$; $\mathrm{p}<0.02)$.

When asked about monitoring during solfège practicing and evaluation of outcomes, a relatively high number of students (53\%) reported that they used previous knowledge and skills in defining the problems needing to be solved, which reflects a transfer of existing skills to new situations. About $1 / 3$ think that they acquired new skills and learned while practicing solfège (36\%) and $1 / 5$ only "worked out" a task, with no insight into the learning process or the possible effects of learned materials and skills.

\section{Sight-singing Strategies related to Students' Learning Experience}

Significant differences considering cognitive strategies for sight-singing and diverse learning experience and general variables appeared. Namely, performers more often drew on the micro-level of tone relations (intervals, motives, tonal relations) $\left(\chi^{2}=5.46(1) ; \mathrm{p}<0.02\right)$, while music theorists (all students except performers) focused on harmony flow $\left(\chi^{2}=4.66(1) ; p<0.03\right)$. We could understand the former as using a more linear approach, focusing on the current position, more often using "tone-to-tone" or "interval-tointerval" thinking and "bottom-up" strategies in approaching the musical structure, and the latter as having better insight into the whole and using "top-down" strategies.

Students who had been learning solfège for a longer period of time were more likely to rely on scale degrees as easy elements $(r=0.24 ; \mathrm{p}<005)$, which 
displays the use of functional thinking in sight-singing. This finding leads to the conclusion about embedded functions of the tonal system which can be said to "work" automatically. This finding is in concordance with the following. Those students who had learned solfège for less time ( 1 to 5 years) often sang the tonic as a strategy to find other pitches $\left(\chi^{2}=11.34(2) ; \mathrm{p}<0.00\right)$ while those who had learned for a longer period of time (6 to 15 years) relied on the harmony flow of the melodic example $\left(\chi^{2}=6.31(2) ; \mathrm{p}<0.04\right)$, hence developing harmonic thinking. This is coupled with our finding that students with a short solfège training (less than 5 years) considered modulation "always difficult" $\left(\chi^{2}=13.90(2) ; \mathrm{p}<0.00\right)$. Analyzing the example before singing was significantly more often the case with women musicians $\left(\chi^{2}=4.05\right.$ (1); $\mathrm{p}<0.05)$. No specific results refer to instrumental groups. It is interesting that future performers, with growing experience in instrumental training, relied more on their musical intuition $\left(\chi^{2}=6.04(2) ; \mathrm{p}<0.05\right)$. Concerning strategies for solving problems, when facing them, there is a difference between the students in The Hague and Belgrade: the former were more apt to analyze the reasons for mistakes made $\left(\chi^{2}=7.60(1) ; \mathrm{p}<0.00\right)$ and the latter to apply already learned methods $\left(\chi^{2}=3.92(1) ; \mathrm{p}<0.05\right)$.

\section{Conclusion}

The findings showed that there is an interplay of learned knowledge and skills on the one hand and reflective processes on the other, and that cognitive strategies can be taught and learned. Students exhibited diverse strategic approaches in the phase of preparation, practicing, defining and solving problems during sight-singing. We could say that learned strategies are prevalent and mostly refer to functional thinking, to tonal and harmonic knowledge. Analysis of the melody before singing and perceiving units of the higher music hierarchy level are also present, and segmentation, as part of an insight into the whole of the example, takes place on the micro and medium levels. Intuitive approaches are also indicated as a highly embedded or tacit knowledge of basic patterns of melodic and harmonic flow. Students, to a certain extent, had a clear awareness about their "strong" and "weak" points, and also strategies for how to solve difficulties - again using the existing knowledge, then analysis, and "auxiliary strategies" (using an instrument). Subsequent research should examine the students in actual singing to check how accurate their estimation is. Students who estimate their sight-singing skills highly do not solve problems using dysfunctional strategies or drill. They analyze the example and have an inner musical representation of it before singing. There remains the question to what extent sight- singing is a matter of learned skills and to what extent it has to do with the level and quality of abilities. 
The results of this pilot research gave some directions for further investigation and eventual improvement of teaching practices. One of the issues that arose is the question of where we want to place sight-singing, on a line between musical action and "strategic game". Should we teach students to focus more on musical flow while sight-singing, or should we train them to be better players of "strategic games"? Whatever the answer, we may want to upgrade the level of the students' understanding in the learning process, and to apply new knowledge in teaching methods, with an emphasis on analysis, reflection and meta-cognitive strategic approaches in each phase of the process. In this way, students' self-regulative learning could be raised, which assumes knowing one's "weak and strong points", having one's own set of strategies that can be used in daily mastering of diverse musical tasks, and therefore selfefficacy, autonomy and independence in the learning process. The next step could be to investigate the possibilities of transferring students' sight-singing skills to learning and practicing of sight-playing a musical instrument.

\section{References}

Beočanin-Mijanović, J. (2008). Between mistake and inertia of the ear in aural skills. Kragujevac: Filum.(Serb.)

Borkowski, J.G. \& Turner, L.A. (1990). Transsituational characteristics of metacognition, in W. Schneider \& F.E.Weinert (Eds.), Interactions among aptitudes, strategies and knowledge in cognitive performance (159-176). New York: Springer.

Ginsborg, J. (2006). Strategies for memorizing music, in A. Williamon (Ed.): Musical excellence. Strategies and techniques to enhance performance (123-143). New York: Oxford University Press.

Hallam, S. (2001). The development of metacognition in musicians: Implications for education. British Journal of Music Education, 18, 27-39.

Hallam, S. (2006). Music psychology in education. London: Institute of Education, University of London.

Jorgensen, H. (2004). Strategies for individual practice, in A. Williamon (Ed.): Musical excellence: strategies and techniques to enhance performance (85-104). Oxford: Oxford University Press.

Karpinski, G.S. (2000). Aural skills acquisition. The development of listening, reading and performing skills in College-level musicians. Oxford: Oxford University Press.

Kopiez, R. \& Lee, J.I. (2006). Towards a dynamic model of skills involved in sight reading music. Music Education Research, 8, 1, 97-120.

Kopiez, R. \& Lee, J.I. (2008). Towards a general model of skills involved in sight reading music. Music Education Research, 10, 1, 41-62.

Kostić, A. (2010). Cognitive psychology. Belgrade: Institute for Handbook Publishing. (Serb.)

Kršić Sekulić, V. (2009). Inner hearing training in a function of immediate preparation for public performance, in G. Karan (Ed.): Proceedings Book of $11^{\text {th }}$ Educational 
Forum: Movement in Music and Stage Arts (28-41). Belgrade: Faculty of Music in Belgrade. (Serb.)

Lehmann, A. C., Sloboda, J.A. \& Woody, R.H. (2007). Psychology for musicians. Understanding and acquiring the skills. New York: Oxford University Press.

Lehmann, A.C. \& Chaffin, R. (2008). Erinnern und Wiedererkennen: Auswendig- und Vomblatt-spiel, in H. Bruhn, R. Kopiez \& A.C. Lehmann (Hg.): Musikpsychologie. Das neue Handbuch (354-373). Reinbek bei Hamburg: Rowohlts Enzyklopädie.

Lehmann, A.C. \& Kopiez, R. (2008). Sight-reading, in S. Hallam, I. Cross \& M. Thaut (Eds.): Oxford handbook of music psychology (344-351). Oxford: Oxford University Press.

Lehmann, A.C. \& McArthur, V. (2002). Sight-reading, in R. Purncutt \& G.E. McPherson (Eds.), The science and psychology of music performance. Creative strategies for teaching and learning (135-150). Oxford, New York: Oxford University Press.

McPherson, G.E. (1994). Factors and abilities influencing sight-reading skill in music. Journal of the Research in Music Education, 42, 3, 217-231.

Nielsen, S.G. (1999). Learning strategies in instrumental music practice. British Journal of Music Education, 16, 275-291.

Nielsen, S.G. (2001). Self-regulating learning strategies in instrumental music practice. Music Education Research, 3, 155-167.

Radoš, K. (2010). Psychology of Music (2 ${ }^{\text {nd }}$ ed.). Belgrade: Institute for Handbook Publishing. (Serb.)

Sloboda, J.A. (1985). The musical mind. The cognitive psychology of music. Oxford: Oxford University Press.

Sloboda, J. (1988). Generative processes in music. Oxford: Clarendon Press.

Sloboda, J.A., Davidson, J.W., Howe, M.J.A. \& Moore, D.G. (1996). The role of practice in the development of performing musicians. British Journal of Psychology, 87, 287-309.

Smilde, R. (2009). Musicians as lifelong learners: Discovery through biography. Delft: Eburon.

Thompson, S. \& Lehmann, A.C. (2004). Strategies for sight-reading and improvising music. In A. Williamon (Ed.), Musical Excellence (143-162). Oxford: Oxford University Press.

Todorović, D. (1995). Visual perceiving and vocal reproduction of melody flow - sight singing. Master thesis, Faculty of Music, University of Arts, Belgrade.

Vujović, I. (2012). The concept of lifelong learning and its possible realization in the framework of solfege, in M. Petrović (Ed.): Proceedings Book of the $14^{\text {th }}$ Pedagogical Forum (in print). Belgrade: Faculty of Music, University of Arts. (Serb.)

Vujović, I. \& Bogunović, B. (2012a). Cognitive strategies in sight-singing, in E. Cambouropoulos, K. Tsougras, P. Mavromatis \& K. Pastiadis (Ed.), Proceedings Book of 13th ICMPC/ESCOM Conference (in print). Thessaloniki: School of Music Studies, Aristotle University of Thessaloniki.

Vujović, I. \& Bogunović, B. (2012b). Sight singing: Musical skill or reflexive strategy. In M. Petrović (Ed.), Proceedings book of the $14^{\text {th }}$ conference Educational Forum of Stage Arts (in print). Belgrade: Faculty of Music, University of Arts. (Serb.) 
Whitaker, N.L. (1996). A theoretical model of the problem solving and decision making of performers, arrangers, conductors and composers. Bulletin of the Council for Research in Music Education, 128, 1-14.

Willingham, D.T. (2007). Cognition. The thinking animal ( $3^{\text {rd }}$ ed.). New Jersey: Pearson Prentice Hall.

Witkin, H.A., Moore, C. A., Goodenough, D.R. \& Cox, P.W. (1977). Field-dependent and field-independent cognitive styles and their educational implications. Review of Educational Research, 47, 1-64.

DATUM PRIHVATANJA RADA: 5. 11. 2012.

\title{
Metakognitivne strategije tokom pevanja s lista
}

\author{
Blanka Bogunović \\ Fakultet muzičke umetnosti, Univerzitet umetnosti u Beogradu
}

\section{Ida Vujović}

Kraljevski konzervatorijum, Hag

Članak predstavlja deo studije koja je zasnovana na interdisciplinarnom istraživanju pevanja s lista (psihologija muzike i muzička pedagogija). Naša namera je da povežemo psihološko znanje o kognitivnim procesima i praktični pristup nastavnika muzike, baziran na metodama, tehnikama i procedurama ovladavanja veštinama pevanja s lista. Nameravali smo da: 1. utvrdimo vrste i nivoe strategija kognitivnih procesa koje studenti muzike koriste tokom pevanja s lista; 2 . istražimo strategije rešavanja problema kada se teškoće pojave; 3. ispitamo aspekte samoevaluacije studenata; 4 . dovedemo u vezu kognitivne strategije koje studenti koriste s prethodnim iskustvom u učenju. Uzorak čini 89 studenata visokog muzičkog obrazovanja iz Beograda i Haga. Oni su popunjavali upitnik koja pokriva opšte podatke o njihovom muzičkom obrazovanju, različitim pitanjima pevanja s lista, kao što su planiranje, rešavanje problema, monitoring i evaluacija ishoda, kao i tri melodijska primera napisana u različitim muzičkim stilovima. Rezultati ukazuju na to da se strategije korišćene tokom pevanja s lista mogu grubo svrstati u tri grupe koje se razlikuju prema „ključnim akcentima”: kognitivne, intuitivne i bez strategije. Muzičke kognitivne strategije uključuju tri nivoa muzičke organizacije i reprezentacije: a) oslanjanje na manje sklopove muzičkog komada uz povezivanje $s$ postojećim znanjem i iskustvom; b) oslanjanje na neznatno „veću sliku” poznatih sklopova; c) mentalnu reprezentaciju melodijsko/harmonskih struktura. Kada je suočena s problemom, većina studenata koristi analitičke strategije. Poređenja poduzoraka pokazuju da, na primer, muzički izvođači u pristupu muzičkoj strukturi češće koriste razmišljanje „od tona-do-tona” i strategije usmerene od „dole prema gore", dok studenti teoretskih odseka imaju bolji uvid u celinu i koriste strategije usmerene od „gore prema dole”. Nalazi stvaraju mogućnost za evaluaciju ishoda učenja i unapređivanje (poboljšanje) prakse podučavanja.

Ključne reči: veštine pevanja s lista, metakognitivne strategije, samoregulativno učenje. 